\title{
The Polish Cultural and Scientific Heritage at the dawn of the Third Millennium, red. E. Szczepanik, London 2003, ss. 738 + ilustracje
}

Odpowiedzialne pochylanie się nad przeszłością i twórcze sięganie do niej jest jedną z niezwykłych możliwości człowieka jako istoty rozumnej i wolnej, a zatem i odpowiedzialnej. Tylko on, jako niepowtarzalna indywidualna osoba, jest zdolny świadomie do tego typu działania. Dotyczy to tak własnej, indywidualnej przeszłości, jak i przeszłości innych osób oraz różnorodnych społeczności, czy wspólnot. To swoiste cofanie się w czasie może przybierać różne znamiona, wyrazy, charakter, czy zakres. Tutaj specyfikacje mogą być niezwykle zróżnicowane. Niemniej zawsze jest to ów świadomy namysł konkretnej osoby, choć może on być przeprowadzany w różnym celu. Często w całości refleksji historycznej istotne bywają także tego konsekwencje, choć nie zawsze są uświadamiane.

Sięganie do przeszłości, to sięganie do bezpowrotnie zamkniętego dziedzictwa, które ostatecznie nie jest obojętne zarówno dla teraźniejszości, jak i przyszłości. Przeszłość jest bowiem znakiem przemijania, ale jednocześnie kreślenia perspektyw. Oczywiście, prowadzone badania mogą ujawnić nowe szczegóły dotyczące znanych tematów, a niekiedy bardziej pogłębione i szersze spojrzenie, które jest zwłaszcza domeną uczonych. Owa otwartość jest jednocześnie znakiem gotowości badawczej, co stanowit ważny element wszelkich poszukiwań naukowych.

W tym kontekście zatem dobrze się stało, że Polskie Towarzystwo Naukowe na Obczyźnie - niezwykle zasłużona instytucja kulturalno-naukowa - wydało monumentalne dzieło pt. The Polish Cultural and Scientific Heritage at the dawn of the Third Millennium pod redakcją prof. dr. Edwarda Szczepanika. (London 2003, ss. 738 + ilustracje). Wpisuje się ono twórczo w dynamizm odpowiedzialnego pochylania się nad dziejami Polski i Polaków, które dziś liczą już ponad tysiąc lat.

Publikację otwiera spis treści i krótki wstęp pióra Redaktora. Całość podzielona została na cztery wielkie części tematyczne. Sam podział jest już bardzo interesującą próbą odpowiedzialnej systematyzacji tak ogromnego materiału. Część pierwsza, pod redakcją A. Suchcitza, poświęcona jest historii politycznej i społecznej. J. Jasnowski wskazuje najpierw na niepodległość 
Polski, a A. Suchcitz, J. Garliński, L. Maik i W. Rojek koncentrują swe analizy wokół działań przeciwko obcej okupacji. O ruchach ludnościowych piszą E. Kruszewski i T. Radzik; ten ostatni koncentruje się zwłaszcza na roli emigracji. Rolę Kościoła ukazał J. Kłoczowski i A. F. Dziuba. Wreszcie w ostatnim rozdziale M. B. Topolska, J. Jurkiewicz, K. Wawruch i J. Hermaszewska zaprezentowali mniejszości religijne i etniczne.

Kolejny blok tematyczny, poświęcony naukom humanistycznym i społecznym, zredagował prof. Z. Wałaszewski. Po ukazaniu historiografii przez J. Wyrozumskiego i J. Serczyka, A. Tomczak i Z. H. Archibald zaprezentowali archiwa, muzea i archeologię. Stosunkowo szeroko literaturę omówili A. Borowski, M. Inglot, S. Eile, W. Bolecki i A. Moskalowa. Filozofię przedstawił J. Woleński, natomiast nauki społeczne J. Gawenda, W. Hładkiewicz, T. Kowalik i J. Szacki.

Prof. S. Portalski jest redaktorem części poświęconej matematyce, naukom przyrodniczym i technologii. K. Tatarkiewicz ukazał matematykę, a B. Orłowski inżynierię i technologię. Szerzej J. Dobrzycki, B. Sredniawa, J. Hurwic, Z. Wójcik, K. Nowak i A. Zemanek zajęli się kolejno astronomią, fizyką, chemią, naukami o ziemi, medycyną i biologią.

Część czwarta, pod redakcją prof. M. Paszkiewicza, ukazuje architekturę, sztukę i kulturę fizyczną. Architekturę, we wspólnym tekście, ukazali Z. Gąsiewicz, A. Czapska i M. Paszkiewicz. Sztuki plastyczne analizuje S. Rodziński, a muzykę A. Grudziński. Dramat i teatr ukazali M. Paszkiewicz i D. Ratajczak, a filmem zajęli się J. Lemann i T. Lubelski. Wreszcie M. Szczerbiński zaprezentował kulturę fizyczną.

Całość dzieła zamyka skromny, chyba zbyt schematyczny, wybór bibliograficzny przygotowany przez J. Jasnowskiego. Natomiast L. Maik przygotował interesujące biogramy o autorach, a M. Brodzińska bardzo szczegółowy indeks osób. Znakomity wybór ilustracji i map, począwszy od „Wprowadzenia chrześcijaństwa w Polsce" pędzla Jana Matejki aż do Jana Pawła II, przygotował T. Piesakowski.

To bardzo schematyczny szkic zawartości treściowej oraz autorów zamieszczonych tekstów, ale wydaje się, iż nawet taka formuła wystarczająco wskazuje na szerokie bogactwo treściowe omawianej pracy. Szczegółowa lektura zdecydowanie to potwierdza, wręcz zachęca do pójścia jeszcze dalej i głębiej. Trudno wręcz oprzeć się tak interesującym sugestiom.

Oto po raz pierwszy ukazało się tak monumentalne opracowanie polskiego dziedzictwa kulturowego i naukowego, i to $\mathrm{w}$ języku angielskim, a więc w języku światowym, co czyni je bardziej dostępnym dla szerokiego grona zainteresowanych. Zatem słowa szczególnej wdzięczności dla K. Brodzińskiego oraz jego małżonki należą się za tak znakomite tłumaczenie na język angielski, zważywszy choćby na tak szerokie zróżnicowanie tematyczne oraz treściowe 
i terminologiczne. Z pewnością książka ta będzie cenną, wręcz podstawową, pomocą dla wielu środowisk naukowych i badawczych $\mathrm{w}$ pochylaniu się nad przeszłością Polski, a w pewnym sensie i rozeznawania jej teraźniejszości oraz wychylenia ku odważnie budowanej przyszłości. Oczywiście są to tylko wprowadzające i ogólne dane, ale poprzez swoistą syntezę mogą tym bardziej zachęcać do sięgnięcia do bardziej interesujących szczegółów, w czym może także pomóc zarówno wspomniana bibliografia ogólna, jak i bibliografia zamieszczona przy wielu tekstach szczegółowych.

Należy także wskazać na wątek polonijny omawianego dzieła, co akcentuje także we wstępie prof. dr E. Szczepanik, wybitny uczony i ostatni premier rządu na uchodźstwie. Nie ulega bowiem wątpliwości, iż - w ramach procesów integracyjnych - znaczna liczba młodzieży polskiego pochodzenia nie posługuje się już czynnie, czy nawet biernie językiem polskim. Jednocześnie, bardzo często, dorastając jest coraz bardziej świadoma, czasem nawet wręcz z wielką determinacją dąży do poznania polskiego dziedzictwa, swojego pochodzenia oraz korzeni przodków. Widać to szczególnie na przykładzie rodaków żyjących w USA, czy Kanadzie. Wydaje się zatem, że prezentowane opracowanie będzie dla wielu szczególnie znaczącą pomocą kulturową i historyczną, nie tylko edukacyjną, ze względu na edycję w języku angielskim.

Nie można także pominąć szerszego znaczenia prezentowanego opracowania dla wszystkich, zresztą coraz liczniejszych, cudzoziemców zainteresowanych dziejami Polski i Polaków. Należy sądzić, iż zainteresowanie to będzie jeszcze bardziej wzrastać, choćby w ramach procesów jednoczenia się Europy, czy coraz powszechnejszej wielopłaszczyznowej globalizacji. Można sądzić, iż książka ta stanie się bardzo szybko swoistym vademecum spraw polskiego dziedzictwa kulturowego i naukowego nie tylko w kręgu anglojęzycznym.

Warto zauważyć, iż prace nad tym dziełem rozpoczęły się już w 1996 r. Zatem zrozumiałym jest, że niektóre teksty nie podejmują wydarzeń, które dokonały się na przestrzeni ostatnich lat, a które byłyby godne odnotowania i omówienia. Co więcej, zwłaszcza ze względu na swoiste znaczne przyspieszenie historii i przemian w Polsce miały duże znaczenie. Zresztą wiele procesów ogólnej historii także nabrało zdecydowanego przyśpieszenia i przewartościowania. Fakt ten nie jest jednak minusem, ale swoistym usprawiedliwieniem ewentualnych uwag w tym zakresie.

Należy docenić ogromny wysiłek zespołu redakcyjnego pod kierunkiem prof. E. Szczepanika oraz głównego redaktora prof. J. Jasnowskiego, jak i redaktorów poszczególnych części, w przygotowaniu tak monumentalnego studium. Koordynacja prac w tak kompleksowym dziele dowodzi znakomitej zdolności organizacyjnej oraz edytorskiej Polskiego Towarzystwa Naukowego na 
Obczyźnie. Zresztą Towarzystwo pokazuje to kolejny raz, ma bowiem niezwykłe zasługi w tym względzie; żeby przywołać choćby przykładowo Materiały do dziejów polskiego wychodźstwa niepodległościowego 1939-1991. Dziś są to już klasyczne zbiory do badań nad powojennymi dziejami Polski i Polonii.

Szczególne gratulacje należą się zespołowi redakcyjnemu ze względu na zgromadzenie tak wielu autorytetów naukowych w zakresie prezentowanych dyscyplin naukowych, czy omawianych zagadnień, którzy zdecydowali się przygotować poszczególne teksty. Idzie tu o tak szeroką rzeszę uczonych pracujących zarówno w kraju, jak i poza jego granicami. Zamieszczone na końcu biogramy są wręcz swoistą ucztą duchową poznania w pigułce tych ludzi, ich dróg oraz osiągnięć naukowych.

Ze względu na tak wielu autorów poszczególnych tekstów można niekiedy zauważyć pewne powtórzenia. Niemniej w praktyce nie należy traktować ich jako mankamentu, ale jako próby spojrzenia $\mathrm{z}$ różnego punktu na te same wydarzenia, tych samych ludzi, czy szerzej, na te same fenomeny historii. Jest to także pouczające i pobudzające do bardziej osobistej refleksji, własnego namysłu nad znakiem historii oraz własnym jej rozeznaniem.

W kontekście szerokiego przeznaczenia prezentowanej pracy trzeba docenić zamieszczoną propozycję różnych ilustracji, fotografii oraz map. Taki materiał może być bowiem cennym poglądowo, zwłaszcza dla szerokich kręgów polonijnych, dla których niejednokrotnie przywiązanie do symboli historycznych ma zupełnie inny sens i rozeznanie twórcze.

Czytając poszczególne opracowania, ukazuje się wyjątkowy obraz przeszłości Polski oraz wielu ludzi ją tworzących. Faktycznie jest to niezwykłe dziedzictwo, zarówno samo w sobie, jak i w zestawieniu z innymi państwami, czy narodami Europy. Niestety, jest ono zbyt mało znane, a - co gorsza - często mało cenione. Brakuje niejednokrotnie pozytywnej dumy $\mathrm{z}$ tych korzeni i fundamentów, narastających poprzez wieki. Może opracowanie to stanie się pewną pomocą oraz wskazaniem dróg, a nawet choćby ścieżek, rozkochiwania się samemu w dziedzictwie Polski i Polaków.

Dokonujące się procesy integracji europejskiej wyzwalają dodatkowe oczekiwania informacyjne, także wobec Polski. Potrzebne są dane, w miarę szeroko dostępne. Wydaje się, że omawiana książka w nie się twórczo wpisuje, tak treściowo, jak i formalnie, przekazując bardzo interesujące kompendium wiedzy o naszym dziedzictwie narodowym, zwłaszcza w płaszczyźnie nauki i kultury. Mieszkańcy Europy poprzez tę książkę mogą się wiele dowiedzieć, a być może i wiele nauczyć.

Należy wyrazić nadzieję, iż prezentowane dzieło będzie dla wielu czytelników, a także różnych instytucji, ważnym wprowadzeniem $\mathrm{w}$ refleksję 
nad dziedzictwem kulturowym i naukowym Polski, zarówno w kraju, jak i poza granicami. Niemal każdy czytelnik znajdzie tu wiele ogólnych, wręcz fundamentalnych i wiodących oraz jednocześnie szczegółowych treści w tym zakresie. Dobrze, że nie zabrakło i bardziej ogólnych odniesień do historii Polski. Ten kontekst jest bardzo ważnym i jednocześnie pomocnym w poprawnym rozeznawaniu szczegółowego bogactwa historii Polski.

Bp Andrzej F. Dziuba 